\title{
Emerging economy business cycles: Financial integration and terms of trade shocks
}

\author{
Rudrani Bhattacharya, Ila Patnaik ${ }^{\dagger}$ Madhavi Pundit ${ }^{\ddagger}$
}

\section{March 2013}

\begin{abstract}
This paper analyses the extent to which financial integration impacts the manner in which terms of trade affect business cycles in emerging economies. Using a small open economy model, we show that as capital account openness increases in an economy that faces trade shocks, business cycle volatility reduces. For an economy with limited financial openness, and a relatively open trade account, a model with exogenous terms of trade shocks is able to replicate the features of the business cycle.
\end{abstract}

JEL Classification: F4, E32

Keywords: Macroeconomics, Real Business Cycles, Emerging Market DSGE Models, Volatility, Terms of Trade.

Authors' E-mail Addresses: rudrani.isi@gmail.com, ilapatnaik@gmail.com, mpundit@adb.org

\footnotetext{
* National Institute of Public Finance and Policy, India $\dagger$ National Institute of Public Finance and Policy, India

${ }^{\ddagger}$ Economics Research Department, Asian Development Bank, Philippines
} 


\section{Contents}

1 Introduction $\quad 3$

2 Openness in emerging markets $\quad 5$

2.1 Financial versus trade openness . . . . . . . . . . . . . . 6

2.2 Relative volatility of the terms of trade . . . . . . . . . . . 7

2.3 Current account volatility . . . . . . . . . . . . 8

3 Case of India $\quad 9$

3.1 Limited financial openness . . . . . . . . . . . . . . . . . . . 9

3.2 Role of terms of trade . . . . . . . . . . . . . . . . . . . 10

4 Model 12

5 Calibration $\quad 15$

$\begin{array}{llr}6 & \text { Results } & 17\end{array}$

6.1 Financial openness and volatility . . . . . . . . . . . . . . 17

6.2 Business cycle features of an emerging economy . . . . . . . . . . . 19

7 Conclusion $\quad 21$ 


\section{Introduction}

Emerging economies differ in the extent of international trade and financial integration. While most emerging economies have opened their trade accounts, they have retained different degrees of control over their capital accounts. The international business cycle literature suggests that financial integration may play a role in determining the volatility of domestic business cycles in an emerging economy in various ways. The composition, magnitude and the cyclicality of capital flows may determine how financial openness impacts macroeconomic variables. On the other hand, financially closed economies may be unable to share risk which again affects domestic volatility. Therefore, financial integration may affect the extent to which economies are able to absorb external shocks (Cakici, 2011; Buch et al., 2005; von Hagen and Zhang, 2006; Levchenko, 2004)

In this paper, we study one aspect of this relation, namely the role of the level of financial openness on the propagation of an exogenous terms of trade (ТОт) shock on business cycle volatility in an emerging economy. A country with an open current account, but closed capital account is likely to have lower ability to absorb TOT shocks. This is because if trade has to balance in each period, current account volatility will be low, and a shock is expected to propagate to output, consumption and investment. On the other hand, when the capital account is open, agents can borrow and lend in international financial markets to smooth their consumption. They are less constrained and do not need to balance the trade account in each period. External TOT shocks may be absorbed and not transmitted to macroeconomic variables. Hence higher terms of trade volatility is expected to lead to higher volatility of output in an economy with low capital account openness.

As emerging economies are being exposed to international markets, a body of literature is developing recently on the relation between integration and volatility. For example, Kose et al. (2003) and Evans and Hnatkovska (2007) study the impact of financial integration in stabilizing the business cycle volatility of emerging markets. We extend this literature by highlighting the role that financial integration could play in determining the volatility of domestic macroeconomic variables, in the presence of an exogenous terms of trade shock. Being commodity traders, emerging economies face exogenous price shocks in the world market which determine domestic business cycle fluctuations (Mendoza, 1995; Kose, 2002). This paper contributes further to this discussion by examining differences in the response of different emerging economies to terms of trade shocks, and proposing a model for understanding how these shocks are propagated.

The model embodies features of an emerging economy and is related to the recent literature studying emerging economy business cycles, especially those focussing on external shocks. A strand of literature studies shocks in the financial markets due to an open capital account. Neumeyer and Perri (2005) relate interest rate fluctuations in international financial markets to the business cycle of emerging markets. Uribe and Yue (2006) find that besides interest rate shocks, fluctuations in the country spread can explain the business cycle. Based on this, Garcia-Cicco 
et al. (2010) and Chang and Fernández (2010) show that the business cycle in an open emerging economy is driven by external shocks to the country's interest rate premium in conjunction with financial frictions. These models, however, do not adequately explain features of the business cycle, especially the lower volatility of the trade balance to output ratio relative to the volatility of output seen in the data.

Data shows that emerging economies exhibit heterogeneity in the nature of openness. We compare the level of trade openness (gross trade as a percent to GDP) and financial openness (external assets and liabilities as a percent to GDP) for a group of emerging economies. We find a wide range in the degree of trade versus financial openness. In general, while Asian economies have higher relative trade openness, Latin American countries have lower relative trade openness and are more financially open. Further, by looking at the relation between the nature of openness and the terms of trade fluctuations, we observe that in countries which have limited capital openness and more open trade accounts, the ratio of TOT volatility to output volatility is lower. This motivates the hypothesis that financial openness plays a role in the relation between TOT shocks and business cycle volatility.

We present a small open economy real business cycle model. In the model, we vary the level of financial integration from full capital mobility to financial autarky. In addition to a productivity shock, we incorporate shocks to the terms of trade as in Mendoza (1995) and Lubik and Teo (2005).

The model is used to analyse the effect of financial integration in two ways: first, we calibrate the model using the parameters of an emerging economy, India, and vary the level of financial integration. We compare the volatility of the business cycle obtained in the economy by assuming increasing levels of financial integration. In the second approach, we calibrate the model to another emerging economy, Brazil, that is similar in most respects, especially in its exposure to terms of trade fluctuations, but is different in the level of financial integration. We compare the performance of the model in its ability to replicate moments from the data for the two economies.

In the first exercise, our results show that the level of financial integration plays a role in the relation between terms of trade shocks and the business cycle volatility. We find that as financial integration increases, volatility of output, consumption and investment declines and the volatility of trade balance to output increases. This is because with higher financial integration, the economy is not constrained in having to balance its current account every period. Volatility in terms of trade does not get transmitted to output, consumption and investment.

We also see that the model broadly matches the features of an emerging economy, India, characterised by trade openness but limited financial openness. It reproduces the relatively higher consumption volatility, countercyclical trade balance, and the lower relative volatility of trade balance to output. In the case of an economy with high financial openness, Brazil, the model is able to replicate the higher relative volatility of trade balance to output. 
Our conclusion that financial openness determines the extent to which a TOT shock is transmitted to the domestic business cycle has important policy implications. In the face of external shocks, capital account openness enables an emerging economy to borrow and lend in the international financial markets and absorb such shocks, and thereby stabilise business cycle volatility.

The rest of the paper is organised as follows: Section 2 documents empirically heterogeneity in openness in emerging countries, the relation to terms of trade volatility and current account volatility. Section 3 uses the example of India to discuss the potential role for terms of trade shocks in explaining the business cycle of an emerging economy. Section 4 discusses a small open economy model with financial integration, and productivity and TOT shocks, and Section 5 calibrates it to an emerging economy. Section 6 discusses the results by varying the level of financial integration and comparing the moments from the model and the data for emerging economies. Section 7 concludes.

\section{Openness in emerging markets}

One of the critical features in which emerging economy business cycles differ from those of advanced economies is the impact of external shocks on the economy and the consequent volatility of macroeconomic variables. The timing, pace and manner of globalisation of emerging economies has varied. In general, in a number of emerging economies, trade openness was undertaken before the capital account was opened.

The reduction in trade barriers depended on the domestic growth environment and development policies and has thus varied across countries. Similarly, different emerging markets opened up their capital accounts at different times and to a varying extent. Many countries still have a number of capital controls in place which restricts their financial openness (Chinn and Ito, 2008; Schindler, 2009; Lane and Milesi-Feretti, 2007). Table 1 presents evidence on the nature of openness for selected emerging economies. ${ }^{1}$

In this setting it is possible to see that the degree of financial openness may determine the extent to which external shocks, such as trade shocks, influence macroeconomic volatility in an emerging economy. An open capital account would allow a country to borrow, and import, even when terms of trade move against it, so as to smooth consumption. A country with a relatively closed capital account would not be able to borrow and would have to absorb a TOT shock by adjusting quantities of exports and imports, such that the current account is more or less balanced (i.e., exports pay for its imports) every period. In the extreme, with financial autarky, a country must have a zero current account deficit and zero volatility of the current account. Changes in the quantities of exports and imports would result in adjustments in output, investment and consumption, and in this way the TOT shock propagates to the macroeconomic variables. On the other hand, borrowing would

\footnotetext{
${ }^{1}$ The emerging markets considered are based on the MSCI country list, with the addition of Argentina.
} 
allow a country to have higher volatility of the current account in the face of trade shocks, and such a shock would not propagate to the real variables. Thus, higher terms of trade volatility would lead to higher volatility of output in an economy with low capital account openness.

\subsection{Financial versus trade openness}

Trade openness is measured as the percent of gross trade, exports plus imports, to $\mathrm{GDP}^{2}$. We use the Lane and Milesi-Feretti (2007) index of financial openness measured by the ratio of the sum of external assets and liabilities to GDP.

Table 1 shows select emerging economies listed in order of the degree of trade openness relative to financial openness. Emerging markets show a wide range in this measure. For example, the data shows that Malaysia is 1.06 times more open with regard to trade flows compared with financial flows, while Argentina is only 0.2 times more open trade-wise.

\begin{tabular}{lrrr}
\hline Table 1 Variation in trade openness relative to financial openness & \\
\hline \hline Country & Trade openness & Financial openness & Trade openness/ \\
& (Exports+Imports/GDP) & (Assets+Liabilities/GDP) & Financial openness \\
\hline Malaysia & 197 & 186 & 1.06 \\
Czech Republic & 119 & 133 & 0.91 \\
Thailand & 114 & 128 & 0.89 \\
Korea & 67 & 84 & 0.87 \\
Hungary & 121 & 167 & 0.77 \\
Philippines & 97 & 127 & 0.77 \\
Poland & 60 & 86 & 0.71 \\
Mexico & 53 & 77 & 0.69 \\
China & 49 & 73 & 0.67 \\
India & 31 & 50 & 0.61 \\
Turkey & 42 & 73 & 0.59 \\
Indonesia & 58 & 105 & 0.58 \\
Russia & 66 & 137 & 0.53 \\
South Africa & 52 & 113 & 0.51 \\
Colombia & 34 & 76 & 0.46 \\
Chile & 64 & 164 & 0.40 \\
Peru & 36 & 111 & 0.32 \\
Brazil & 22 & 76 & 0.29 \\
Argentina & 30 & 149 & 0.21 \\
\hline
\end{tabular}

The table reports the ratio of trade openness to financial openness in emerging economies averaged for the period 1992-2010. Trade openness is measured as the sum of exports and imports as a percent to GDP and financial openness is calculated as the sum of assets and liabilities as a percent to GDP. There is heterogeneity among emerging economies. While the Asian economies show higher relative trade openness, the Latin American countries have lower relative trade openness or higher relative financial openness.

Source: WDI; Lane and Milesi-Feretti (2007)

\footnotetext{
${ }^{2}$ The data are obtained from the World Bank's WDI at an annual frequency and averaged for the period $1992-2010$.
} 
We observe that the south, east and south-east Asian countries, namely Malaysia, Thailand, Korea, Philippines, China and India have more open trade accounts compared to financial accounts. In contrast, Latin American countries, such as Colombia, Chile, Peru, Brazil and Argentina have less relative openness in trade. Mexico, Turkey and Indonesia are similar to India with about 0.6 times more openness in trade than financial flows. While the Czech Republic, Hungary and Poland show higher relative trade openness, Russia and South Africa appear lower in the order. In general, there is significant heterogeneity in the degree of trade openness relative to financial openness among emerging economies.

\subsection{Relative volatility of the terms of trade}

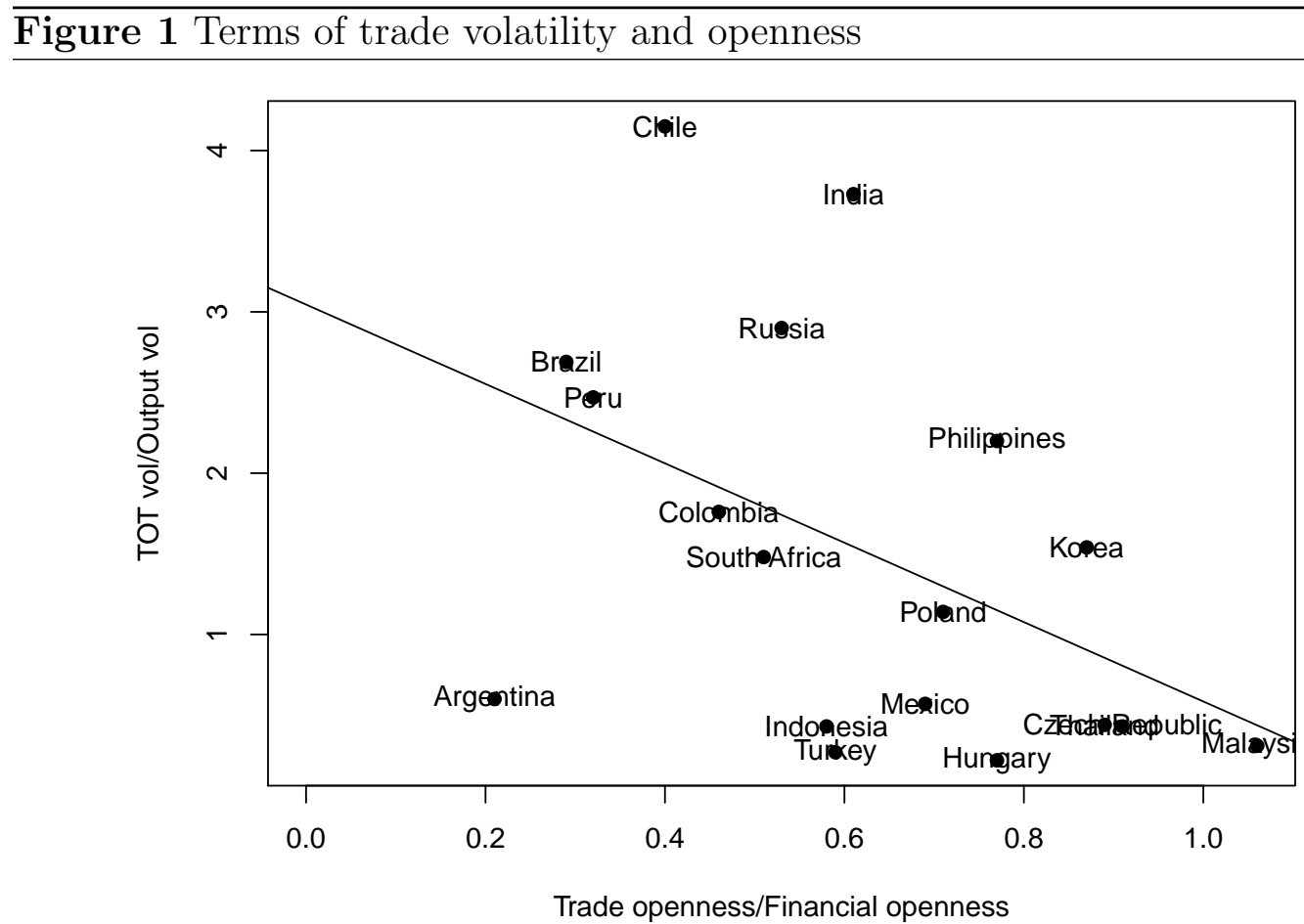

The scatter plot shows the relation between the ratio of trade to financial openness and the ratio of TOT volatility to output volatility for emerging economies. The negative correlation implies that when relative financial openness is low, the ratio of TOT volatility to output volatility is low.

Source: WDI; Lane and Milesi-Feretti (2007); IFS

Figure 1 shows the relation between relative trade openness to financial openness as measured in Table 1 and the relative volatility of тот to output for the group of emerging economies. Movement along the horizontal axis implies higher trade openness and lower financial openness. The cyclical components of the net barter terms of trade and GDP are used to calculate the volatilities ${ }^{3}$. We see a negative relation:

\footnotetext{
${ }^{3}$ Data on net barter terms of trade is obtained from the World Bank's WDI and averaged for the period $1992-2010$.
} 
countries with more closed capital accounts and higher relative trade openness have a lower ratio of TOT volatility to output volatility.

\subsection{Current account volatility}

To explore the hypothesis that when financial openness is high, the economy is not bound to keep current account volatility low, we plot the relation between financial openness using the Lane and Milesi-Feretti (2007) measure and the volatility of trade balance to output ratio (TBY), relative to output volatility for the sample of emerging economies in Figure 2. Volatility is calculated as the percent standard deviation of the cyclical components of TBY and GDP.

Figure 2 Financial openness and current account volatility

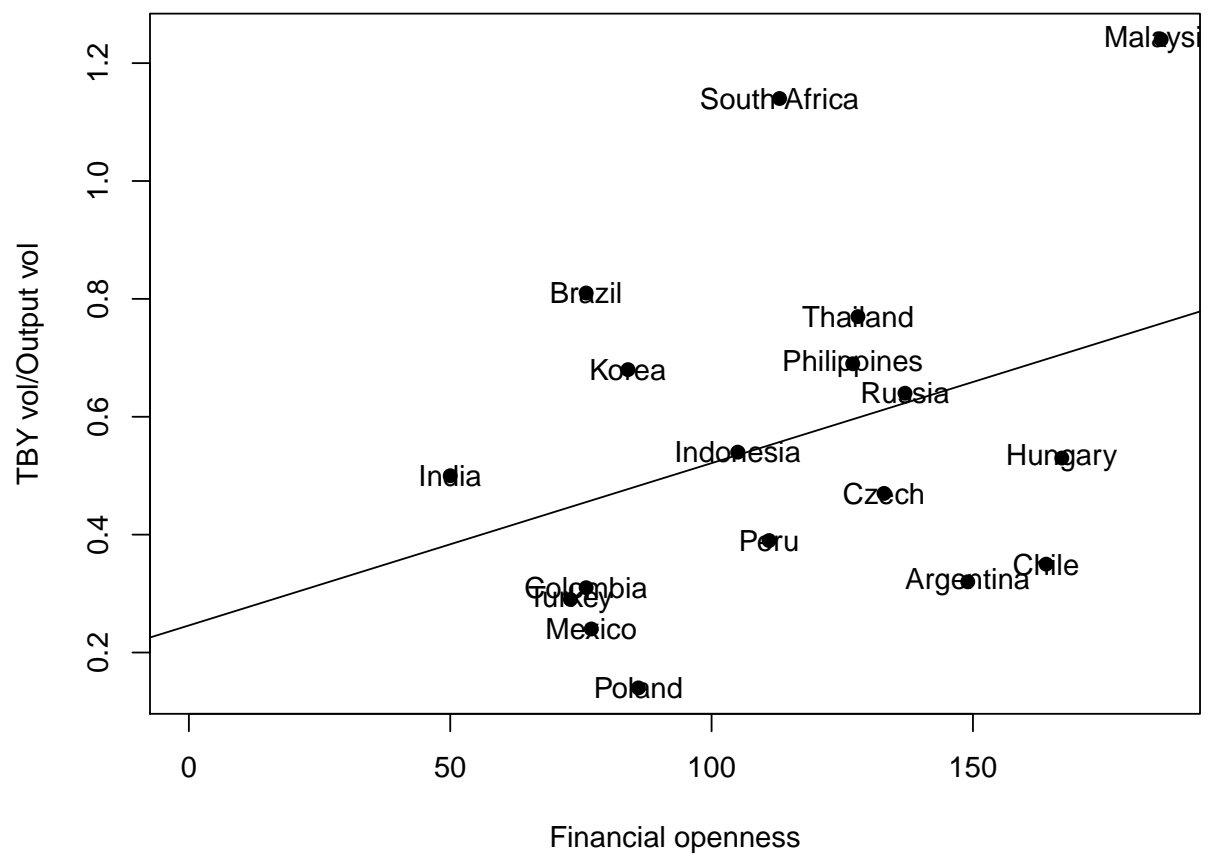

The graph plots the relation between financial openness and current account volatility relative to output volatility. We see a positive relation, i.e., in countries with low financial integration, current account is stable and in countries where financial openness is high, volatility is high.

Source: WDI; Lane and Milesi-Feretti (2007); IFS

The positive relation shows that when financial openness is low, the volatility of TBY is low. For example, according to the Lane and Milesi-Feretti (2007) measure, countries such as Poland, Mexico, Turkey, Colombia etc. have lower levels of financial integration and low levels of relative current account volatility (less that 0.3 percent). On the other hand, in countries that have more capital account openness, current account volatility is high. Take the case of Malaysia, which has the highest financial openness among the economies considered at 186 percent of GDP. The relative volatility of the current account is also highest at 1.24 percent. 


\section{Case of India}

India is an example of an emerging economy with trade openness and low financial openness. By studying the nature of current account volatility, we provide evidence for the potential role of тот shocks in propagating the business cycle.

\subsection{Limited financial openness}

India has a large and complex structure of legal and administrative controls that restrict the flow of capital in the economy (Patnaik and Shah, 2011). Various measures of de-jure capital controls such as Chinn and Ito (2008); Abiad et al. (2008); Quinn and Toyoda (2007) show that India has a relatively closed capital account. As shown in Table 2, this not only implies that India is financially less open, but it is one of the least open among other emerging markets.

A measure of de-jure restrictions at a more disaggregate level of financial transactions is provided by Schindler (2009). The main categories in this dataset, which are further divided into sub-categories are: Shares or other securities of a participating nature; Bonds or other debt securities; Money market instruments; Collective investments; Financial credits; and Direct investment. According to this measure, 0 implies no restrictions, while 1 implies complete restrictions in the categories. India features high in the list among emerging markets, with an average restriction index between $1995-2005$ of 0.89 .

The last column of Table 2 shows a measure of de-facto capital account openness using the Lane and Milesi-Ferreti database. This index is constructed based on a country's external assets and liabilities. Lane and Milesi-Feretti (2007) describe the methodology for the construction of the index. Accordingly, international holdings and transactions are classified as: Portfolio investment, subdivided into equity securities and debt securities; Foreign direct investment; Other investment, which includes debt instruments such as loans, deposits, and trade credits; Financial derivatives; and Reserve assets. The average index for India from 2000 - 2007 stands at 0.58 , which again is one of the lowest among the emerging markets, and shows low level of financial integration. 
Table 2 Measures of financial openness

\begin{tabular}{lcrc}
\hline Country & Schindler & Chinn-Ito & LMF \\
\hline China & 0.96 & -1.13 & 0.87 \\
Russia & 0.93 & -0.52 & 1.56 \\
India & 0.89 & -1.13 & 0.58 \\
Malaysia & 0.84 & -0.09 & 1.96 \\
Morocco & 0.82 & -1.13 & 1.15 \\
Thailand & 0.78 & -0.22 & 1.32 \\
Philippines & 0.75 & 0.14 & 1.36 \\
South Africa & 0.66 & -1.13 & 1.41 \\
Brazil & 0.61 & 0.29 & 0.91 \\
Chile & 0.59 & 1.74 & 1.92 \\
Korea & 0.52 & -0.19 & 1.03 \\
Mexico & 0.52 & 0.92 & 0.76 \\
Hungary & 0.44 & 1.66 & 2.07 \\
Indonesia & 0.44 & 1.18 & 1.01 \\
Argentina & 0.40 & -0.26 & 1.93 \\
Turkey & 0.29 & -1.13 & 0.87 \\
Czech & 0.20 & 2.07 & 1.57 \\
Egypt & 0.05 & 2.29 & 1.09 \\
Peru & 0.00 & 2.53 & 1.12 \\
Colombia & - & -0.61 & 0.89 \\
Poland & - & -0.18 & 1.02 \\
\hline Average & $\mathbf{0 . 5 6}$ & $\mathbf{0 . 3 1}$ & $\mathbf{1 . 2 6}$ \\
\hline
\end{tabular}

The table shows indices of capital account liberalisation in emerging markets. A higher score indicates higher integration due to lower capital controls, except in the case of Schindler (2009), where lower values imply higher restrictiveness. This evidence suggests that India has a relatively closed capital account, and one of the least open when compared to peers.

Source: Schindler (2009); Chinn and Ito (2008); Lane and Milesi-Feretti (2007)

Cross-border financial flows are small, and India's financial integration with the world is limited, as indicated by the de-jure and de-facto measures of capital account openness.

\subsection{Role of terms of trade}

Trade openness is around 30 percent of GDP as shown in Table 1. India has a diversified export basket. However, it is largely a commodity importer, and has a large oil import bill. Like most developing countries, India can be assumed to be a price-taker in the world market, since it cannot influence the prices of the goods that it exports and imports (Broda, 2004; Kose, 2002).

The terms of trade defined as the ratio of the home price at which goods are exported to the foreign price of imported goods in domestic currency, are largely exogenous for India. TOT are usually measured as the ratio of unit price of exports to unit price of imports. Unit value measures are obtained by dividing the current value over the volume, and do not reflect direct price indexes of exports and imports (Mendoza, 1995). In India, we can address this by measuring тот by the ratio of Consumer Price Index for Industrial Workers (CPI-IW) to Wholesale Price Index (WPI). CPI 
contains tradeables and non-tradeables prices and can be considered a proxy for the home price. WPI reflects global prices of tradeables and the fluctuations of the rupee, due to a large share of tradeables in it (Patnaik et al., 2011). This price index can be used as a proxy for foreign price.

Figure 3 plots the cyclical components of GDP, TOT and the ratio of trade balance (exports minus imports) to output (TBY) over the period $1992-2010$. The graph shows that the TOT are highly volatile over the business cycle, with respect to output.

Figure 3 Cyclical pattern

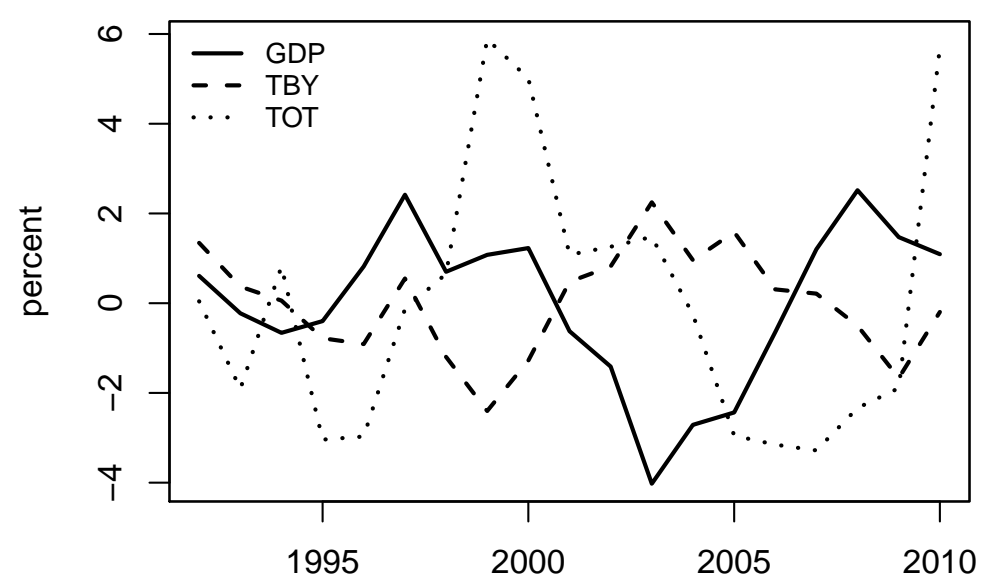

The graph plots the cyclical components of GDP, TOT - measured as the ratio of CPI-IW to WPI, and the ratio of the trade balance to output. While тот is more volatile than output, current account is less volatile.

Source: National sources

As reported in Table 3, the standard deviation of TOT relative to output is 1.7 for the period $1992-2010$. We also take the ratio of CPI to WPI-nonfood and the net barter TOT (unit value of export/unit value of import) as alternate measures of тот. They all show that тот are more volatile than output. While the first two measures suggest a low correlation for TOT with GDP, the third measure shows a higher value.

While тот are highly volatile relative to output, the current account (TBY in Figure 3 ) is seen to be relatively more stable than output (Table 3 shows that the standard deviation relative to output is less than one). Thus in response to exogenous and highly volatile relative price movements, given that the current account is relatively stable, it implies that the quantity of exports and imports are adjusting. The terms of trade shocks may be responsible for fluctuations in the business cycle as seen in the data. 
Table 3 Cyclical features of terms of trade

\begin{tabular}{lrrr}
\hline & CPI/WPI & CPI/WPI(nonfood) & exp price/imp price \\
\hline std. $\operatorname{dev}($ TOT) & 2.97 & 4.13 & 6.97 \\
std. $\operatorname{dev}($ тOT) $/$ std.dev(Y) & 1.71 & 2.38 & 3.73 \\
corr(TOT, Y) & 0.07 & 0.14 & 0.74 \\
\hline
\end{tabular}

The table presents the key moments in the period $1992-2010$, namely volatility, relative volatility and correlation with output for the TOT in India. The ratio of CPI-IW to WPI in India represents тот, and shows that тот are more volatile than output and mildly procyclical at the business cycle frequency.

Based on this empirical evidence on the potential role for terms of trade fluctuations in propagating the business cycle of an emerging economy, we use a small open economy model with exogenous terms of trade shocks to study the effect of financial openness in this relation.

\section{Model}

This section presents a small open economy RBC model for an emerging economy. The degree of financial openness can be varied from full capital mobility to financial autarky. We include terms of trade shocks in the model based on Mendoza (1991) and Lubik and Teo (2005).

\section{Households}

The household maximises its expected discounted lifetime utility

$$
E_{0} \sum_{t=0}^{\infty} \beta^{t} U\left(C_{t}\right)
$$

subject to the resource constraint:

$$
P_{t} C_{t}+P_{t} I_{t}+P_{F t} B_{t}-P_{F T} \frac{B_{t+1}}{1+R_{t}}+\frac{\kappa}{2}\left(\frac{P_{F t}\left(\frac{B_{t+1}}{\Gamma_{t}}-\bar{b}\right)}{P_{H t} \frac{Y_{t}}{\Gamma_{t-1}}}\right)^{2} P_{H t} Y_{t}=P_{H t} Y_{t}
$$

where $Y_{t}$ is output, $C_{t}$ is consumption, $I_{t}$ is investment, and $B_{t}$ is the internationally traded bond denominated in terms of foreign goods. $R_{t}$ is the time $t$ interest rate payable for the debt due in period $t+1$. $P_{F t}$ and $P_{H t}$ denote the prices of foreign and home goods respectively, and $P_{t}$ is the aggregate price index. $q_{t}=\frac{P_{H t}}{P_{F T}}$ is the terms of trade. $\Gamma_{t}$ is the non-stationary labour productivity described below.

Access to world financial markets is assumed to be imperfect. Financial integration is determined by a convex adjustment cost, $\kappa$, to bond holdings, such that $\kappa=0$ implies full integration and $\kappa \rightarrow \infty$ represents financial autarky. The cost can 
be interpreted as taxes and other restrictions on capital account transactions that prevent free mobility.

Capital, $K_{t}$, evolves according to the law of motion:

$$
K_{t+1}-(1-\delta) K_{t}+\frac{\phi}{2}\left(\frac{K_{t+1}}{K_{t}}-1\right)^{2} K_{t}=I_{t}
$$

where $\delta$ is the depreciation rate and $\phi$ is the parameter governing the investment adjustment cost.

Aggregate consumption is assumed to be a Cobb-Douglas function of consumption of domestic goods $C_{H t}$ and foreign goods $C_{F t}$ given by:

$$
C_{t}=\frac{C_{H t}^{(1-\gamma)} C_{F t}^{\gamma}}{(1-\gamma)^{(1-\gamma)} \gamma^{\gamma}}
$$

where $\gamma$ is the share of foreign consumption goods in the basket. Similarly, investment is also a Cobb-Douglas aggregate of domestic and foreign investment goods, $I_{H t}$ and $I_{F t}$. Then the corresponding consumption-based price index is

$$
P_{t}=P_{H t}^{1-\gamma} P_{F t}^{\gamma} .
$$

Thus the resource constraint can be rewritten as:

$$
C_{t}+I_{t}+q_{t}^{\gamma-1} B_{t}-q_{t}^{\gamma-1} \frac{B_{t+1}}{1+R_{t}}+\frac{\kappa}{2}\left(\frac{\frac{B_{t+1}}{\Gamma_{t}}-\bar{b}}{q_{t} \frac{Y_{t}}{\Gamma_{t-1}}}\right)^{2} q_{t}^{\gamma} Y_{t}=q_{t}^{\gamma} Y_{t}
$$

to include the terms of trade, $q_{t}$.

A shock to the terms of trade evolves according to an AR(1) process given by

$$
\ln q_{t}=\rho_{q} \ln q_{t-1}+\epsilon_{t}^{q} ; \epsilon_{t}^{q} \sim N\left(0, \sigma_{q}^{2}\right)
$$

\section{Firms}

Output is produced using a Cobb-Douglas technology with capital and one unit of labour inelastically supplied by the household. It takes the form:

$$
Y_{t}=e^{a_{t}} K_{t}^{1-\alpha} \Gamma_{t}^{\alpha},
$$

where $\alpha \in(0,1)$ represents the share of labour in output, $e^{a_{t}}$ denotes the level of total factor productivity and $\Gamma_{t}$ represents labour productivity. Total factor productivity evolves according to an $\mathrm{AR}(1)$ process as follows:

$$
a_{t}=\rho_{a} a_{t-1}+\epsilon_{t}^{a} ; \epsilon_{t}^{a} \sim N\left(0, \sigma_{a}^{2}\right),
$$

with $\left|\rho_{a}\right|<1$. Labour productivity $\Gamma_{t}$ is non-stationary and defined as

$$
\Gamma_{t}=g_{t} \Gamma_{t-1}
$$

where $g_{t}$ is the growth rate of labour productivity. 


\section{Interest rate and country premium}

Domestic interest rate is assumed to be the sum of the world interest rate $R^{*}>0$, exogenous to the small open economy, and a country premium that is increasing in a detrended measure of aggregate debt (Aguiar and Gopinath, 2007; Garcia-Cicco et al., 2010). The country premium takes the form:

$$
R_{t}=R^{*}+\psi\left(e^{\frac{\tilde{B}_{t+1}}{\Gamma_{t}}-\bar{b}}-1\right),
$$

The total debt of the economy $\tilde{B}_{t}$ is exogenously given to the household, which does not internalise the premium payable on the foreign interest rate determined by the indebtedness of the economy. However, in equilibrium, total foreign debt of the economy coincides with the amount of debt acquired by the household. $\bar{b}$ denotes the steady state level of debt, and $\psi>0$ governs the elasticity of the premium to changes in the indebtedness of the economy. $\psi$ can be regarded as a reduced form of frictions in the economy.

\section{Equilibrium}

For any variable $X$, its detrended counterpart is defined as $x_{t}=\frac{X_{t}}{\Gamma_{t-1}}$. The trend growth is represented by $\mu_{g}$. The households' optimality conditions in stationary form are:

$$
\begin{aligned}
\frac{1}{c_{t}} g_{t}\left[1+\phi\left(\frac{k_{t+1} g_{t}}{k_{t}}-\mu_{g}\right)\right]= & \beta \frac{1}{c_{t+1}}\left[q_{t+1}^{\gamma}(1-\alpha) e^{a_{t+1}} k_{t+1}^{-\alpha} g_{t+1}^{\alpha}+(1-\delta)\right. \\
& +\phi\left(\frac{k_{t+2} g_{t+1}}{k_{t+1}}-\mu_{g}\right)\left(\frac{k_{t+2} g_{t+1}}{k_{t+1}}\right) \\
& \left.-\frac{\phi}{2}\left(\frac{k_{t+2} g_{t+1}}{k_{t+1}}-\mu_{g}\right)\right]
\end{aligned}
$$

and

$$
\frac{1}{c_{t}} g_{t} q_{t}^{\gamma-1}\left[\frac{1}{1+R_{t}}-\kappa\left(b_{t+1}-\bar{b}\right)\right]=\beta E_{t} \frac{1}{c_{t+1}} q_{t+1}^{\gamma-1} .
$$

The resource constraint is

$$
c_{t}+i_{t}+q_{t}^{\gamma-1} b_{t}-q_{t}^{\gamma-1} g_{t} \frac{b_{t+1}}{1+R_{t}}+\frac{\kappa}{2}\left(\frac{b_{t+1}-\bar{b}}{q_{t} y_{t}}\right)^{2} q_{t}^{\gamma} y_{t}=q_{t}^{\gamma} y_{t}
$$

where

$$
\begin{gathered}
i_{t}=g_{t} k_{t+1}-(1-\delta) k_{t}+\frac{\phi}{2}\left(g_{t} \frac{k_{t+1}}{k_{t}}-\mu_{g}\right)^{2} k_{t}, \\
y_{t}=a_{t} k_{t}^{1-\alpha} g_{t}^{\alpha},
\end{gathered}
$$

and

$$
R_{t}=R^{*}+\psi\left(e^{\tilde{b}_{t+1}-\bar{b}}-1\right)
$$


With initial capital stock $k_{0}$ and debt $b_{0}$, the competitive equilibrium is defined as a set of prices $\left(R_{t}\right)$ and quantities $\left(y_{t}, c_{t}, i_{t}, k_{t}, b_{t}\right)$, given the sequence of shocks to $a_{t}$ and $q_{t}$, that solve the maximisation problem of the household, and satisfy the resource constraint and interest rate dynamics.

\section{Calibration}

The model is calibrated for India for the period $1992-2010$. We obtain some of the parameters from the literature, and estimate the rest. The value for financial integration, $\kappa$, is varied over a range. Table 4 summarises the parameter values used in the calibration of the model.

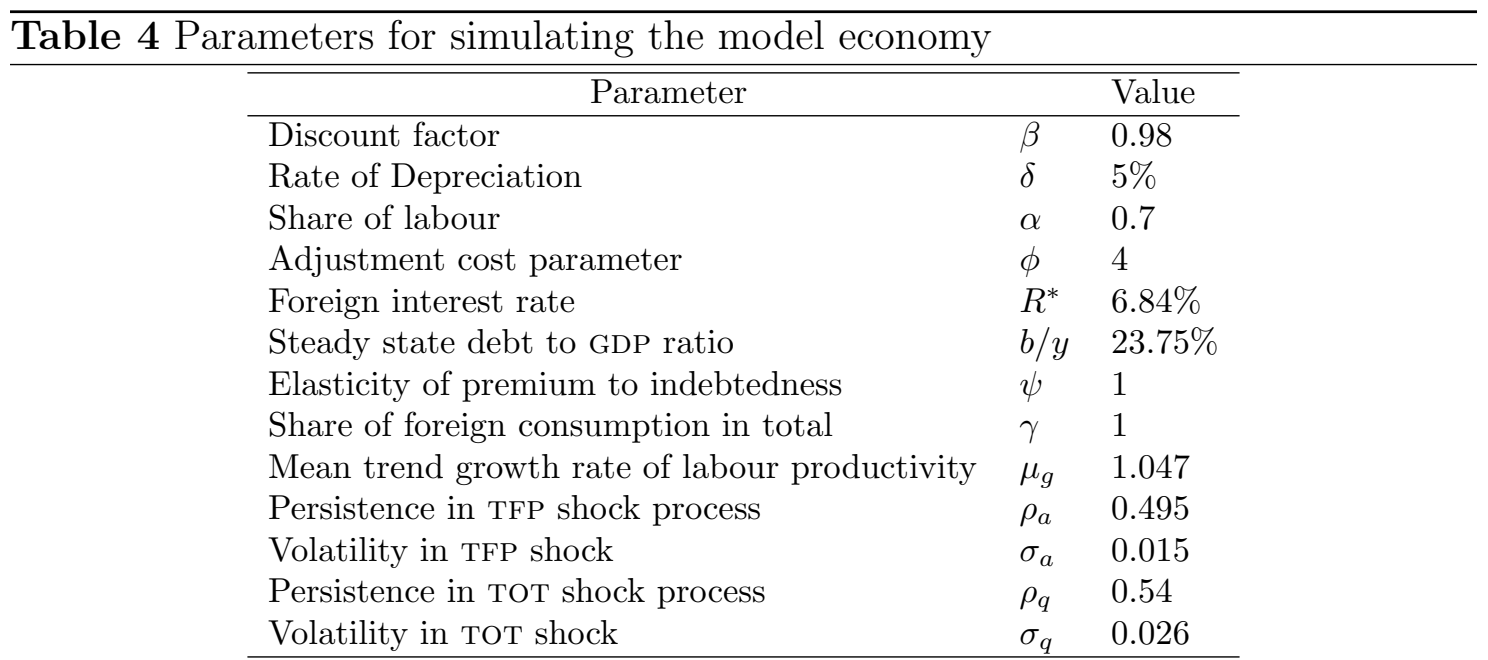

The table summarises the parameters based on the Indian economy for estimating the model. While most of the values are obtained from the literature, the shock processes are estimated using annual data.

One time period in the model is a year. The discount rate $\beta$ is set to 0.98 . The adjustment cost parameter $\phi$ is set to 4 as in Aguiar and Gopinath (2007). The share of labour $\alpha$ is 0.7 from Verma (2008), while the rate of depreciation $\delta$ is assumed to be $5 \%$ as in Virmani (2004). The parameter $\bar{b}$ is set such that the steady state external debt-to-output ratio is 23.75 percent, which is the average in India over the period 1990 - 2010 (GOI, 2011).

Garcia-Cicco et al. (2010) show that a high value of $\psi$, is required for the realistic transmission of a shock that affects the interest rate. The terms of trade shock impacts the interest rate indirectly through its effect on output, consumption, and foreign bonds. A number of studies examine the relation between emerging market spread and macroeconomic fundamentals such as debt, reserves, current account, fiscal variables, GDP growth etc. (Edwards, 1984; Min et al., 2003; Min, 1998; Eichengreen and Mody, 2000). We take the value for $\psi$, the elasticity of the spread to changes in debt-to-output, from Eichengreen and Mody (2000) as 1. 
The value of the risk-free world interest rate is set to satisfy the condition that $\beta\left(1+R^{*}\right)=\mu_{g}$, where $\mu_{g}$ is the mean trend growth rate of labour productivity which is calculated to be 1.047 .

The share of foreign consumption good in the total consumption basket of the household, $\gamma$, is taken as 1 in the baseline parametrisation, since we are considering a small open economy that is completely open in the international goods market. We then vary the value of $\gamma$ in the sensitivity analysis.

The value of $\kappa$, the measure of financial integration, is varied so that we have different levels of financial integration.

\section{Shock process in the total factor productivity series}

In order to obtain the amplitude and persistence of the shock process, we construct the total factor productivity (TFP) for the Indian economy for the period 1980 2009. Aggregate TFP series is computed as the weighted average of sectoral TFP series. Sectoral GDP and the net fixed capital stock data (at $1999-2000$ constant prices at annual frequency) are available from 1951. From 2005 these series are available at $2004-2005$ constant prices. The series for the two variables are linked to their 2004 - 2005 base series to obtain a longer time series.

The distribution of labour force (per 1000 households, male/female, rural/urban) is reported for each sector in the NSSO's quinquennial Employment Unemployment Survey as well as in the annual surveys based on a thin sample. We generate a time series of the distribution of sectoral employment based on these reports. National labour force data published by the World Bank are available from 1980 at annual frequency. Using the sectoral distribution of labour force and the total labour force data, we obtain sectoral employment series. Finally, we measure the sectoral TFP series for India using sectoral real GDP, net fixed capital stock and employment data. Given the availability of employment data, our TFP series span $1980-2009$.

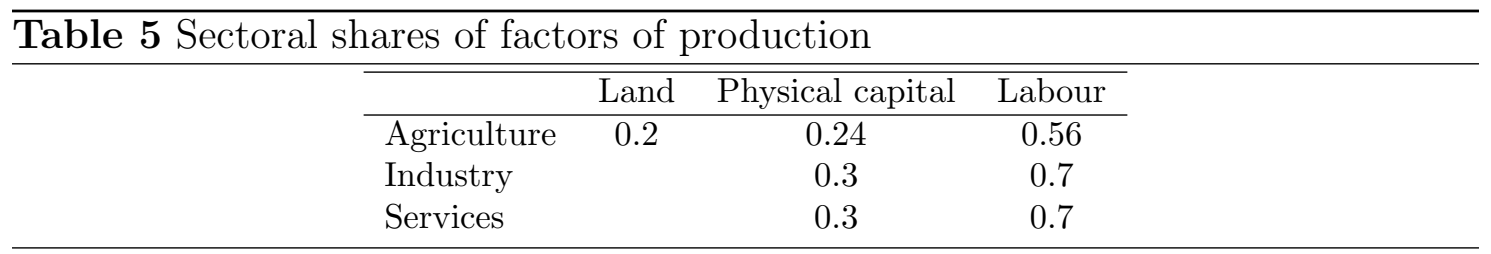

Using the sectoral shares $\left(w_{s}^{j}\right)$ of capital, labour and land in agriculture, industry and services from Verma (2008), shown in Table 5, we measure the sectoral TFP series as

$$
\log \left(A_{t}^{s}\right)=\log \left(Y_{t}^{s}\right)-\sum w_{s}^{j} \log \left(X_{t}^{s j}\right), \quad \sum_{j=1}^{n_{s}} w_{s}^{j}=1,
$$

where $n_{s}$ is the number of inputs used in sector $s$. Here $s$ denotes major sectors constituting the economy namely, agriculture, industry and services, $Y$ represents real GDP and $X^{j}$ denotes factors of production in the respective sector. 
For example when, $s=$ agriculture, $j=$ land, physical capital, labour. When $s=$ industry, services, $j=$ physical capital, labour.

Aggregate TFP is measured as a weighted average of the sectoral TFPs:

$$
\log \left(A_{t}\right)=\sum_{s} \log \left(A_{t}^{s}\right), \quad s=\text { Agriculture, Industry, Services }
$$

Next, we de-trend the TFP series using HP filter with the value of the smoothing parameter $\lambda=100$. We fit an $\mathrm{AR}(1)$ model on the cyclical component of TFP to obtain the persistence parameter $\left(\rho_{a}\right)$ and the standard deviation $\left(\sigma_{a}\right)$ of the residual as 0.495 and 0.015 respectively.

\section{Shock process in the growth of labour productivity}

Using sectoral real GDP and labour force data, we obtain the annual time series of sectoral and aggregate labour productivity for India based on the following formulae:

$$
\begin{aligned}
& \log \left(\Gamma_{t}^{s}\right)=\log \left(Y_{t}^{s}\right)-\log \left(X_{t}^{s j}\right), \quad j=\text { labour } \\
& \log \left(\Gamma_{t}\right)=\sum_{s} \log \left(\Gamma_{t}^{s}\right), \quad s=\text { Agriculture, Industry, Services }
\end{aligned}
$$

The gross growth rate of labour productivity $\frac{\Gamma_{t}}{\Gamma_{t-1}}$ is

$$
g_{t}=1+\Delta \log \left(\Gamma_{t}\right)
$$

Next, we de-trend the growth of labour productivity using HP filter with value of the smoothing parameter $\lambda=100$. The mean trend net growth rate, $\mu_{g}$, over the period $1980-2009$ is estimated as 1.047 .

\section{Shock process in the terms of trade}

We fit an AR(1) model on the cyclical component of TOT, measured as the ratio of CPI-IW to WPI, to obtain the persistence $\left(\rho_{q}\right)$ and standard deviation $\left(\sigma_{q}\right)$ of the residual. The values are 0.54 and 0.026 respectively.

\section{Results}

\subsection{Financial openness and volatility}

Figure 4 plots the volatilities of output, consumption, investment and trade balance to output from the model, for a range of values of $\kappa$, where $\kappa=0$ implies full financial integration and $\kappa=100$ represents financial autarky. The baseline parametrisation has $\gamma=1$ indicating trade openness (the solid black line). 
The key result is that as $\kappa$ increases, volatility of output, consumption and investment increases, i.e., with lower financial openness, the volatility of the business cycle increases in response to a terms of trade shock. The volatility of consumption is above that of output. Further, as expected, the trade balance to output volatility declines as $\kappa$ increases. When the capital account is closed, trade balances each period and the current account volatility is low.

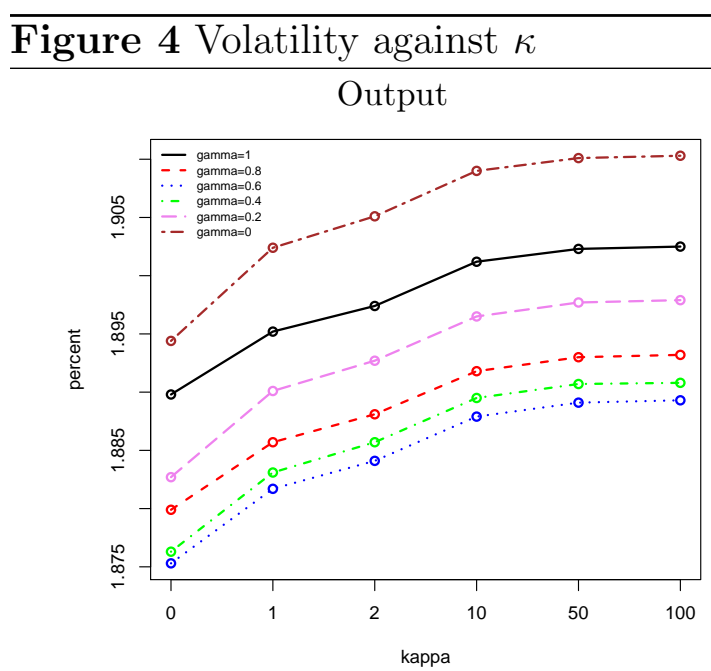

Investment

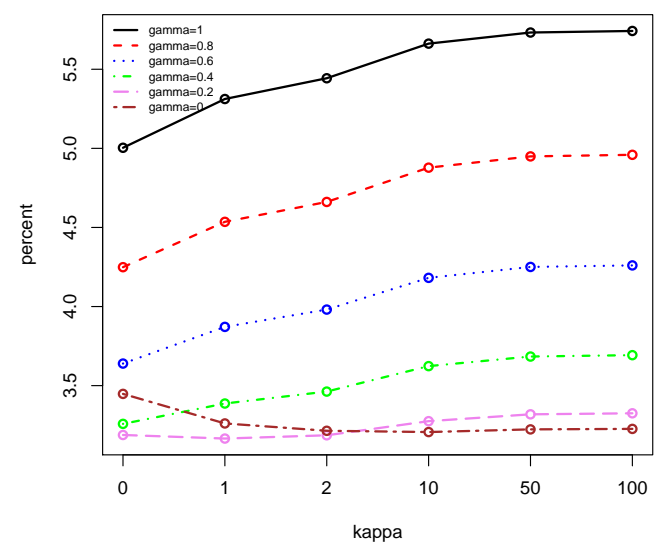

Consumption

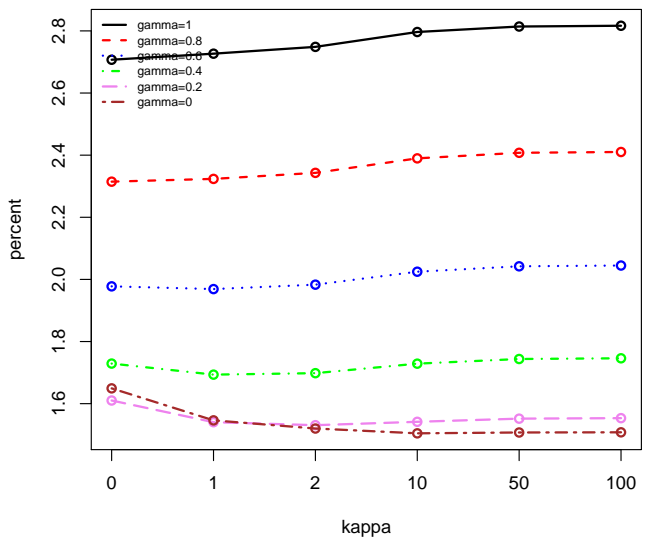

Trade Balance/Output

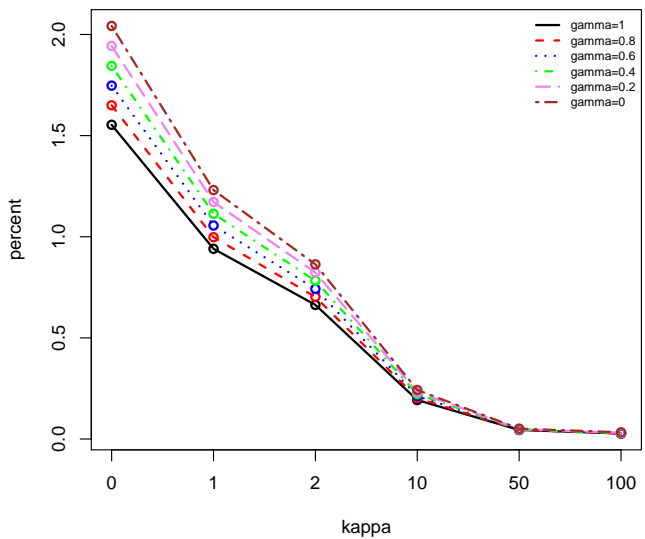

The graphs plot the volatilities of simulated output, consumption, investment and trade balance to output ratio against a range of values for $\kappa$. The relation is obtained for different values of $\gamma$. Lower values of financial integration are associated with higher volatility of output, consumption and investment, and lower volatility of the current account.

\section{Sensitivity analysis}

Figure 4 also plots the volatilities against $\kappa$ for various values of $\gamma$, the parameter that governs the share of foreign consumption goods in total consumption, as well as the share of the foreign price in the aggregate price index.

As $\kappa$ increases, for all values of $\gamma$, output volatility increases and the volatility of TBY decreases. When $\gamma$ is 0.4 and below, i.e., the trade account is relatively closed, 
the volatility of consumption falls below that of output. When $\gamma=0$, the volatility of consumption and investment declines as $\kappa$ increases.

\subsection{Business cycle features of an emerging economy}

We check whether the model with terms of trade shocks can explain the business cycle features of an emerging economy. We compare the moments from the model with the data for an emerging economy that is characterised by limited financial openness and higher trade openness, namely India.

\section{India: Model and data moments}

The key moments of the business cycle, i.e., volatility, relative volatility to output, contemporaneous correlation and autocorrelation are reported in the first row under each category in Table 6. Data on output (GDP), consumption (private consumption expenditure), investment (gross fixed capital formation), TBY or trade-balance-toGDP (ratio of net export to GDP) and TOT (ratio of CPI-IW to WPI) are logged and detrended using the Hodrick Prescott filter to obtain the cyclical components ${ }^{4}$. The time period considered is $1992-2010$. This is the period post reforms, when the economy transitioned to a more market driven system characterised by cyclical movements in output, consumption and investment. In this period, the business cycle properties of India are similar to those documented for other emerging economies (Ghate et al., 2013; Aguiar and Gopinath, 2007). Consumption and investment are more volatile than output, while trade-balance-to-output ratio is less volatile than output. Consumption and investment are procyclical, while TBY is strongly countercyclical. The terms of trade are more volatile than output and mildly procyclical.

The second row reports the moments from the model with full financial integration $(\kappa=0)$. The third row shows the moments for the case of high costs to financial integration $(\kappa=100)$.

\footnotetext{
${ }^{4}$ The data are obtained from National Accounts Statistics.
} 


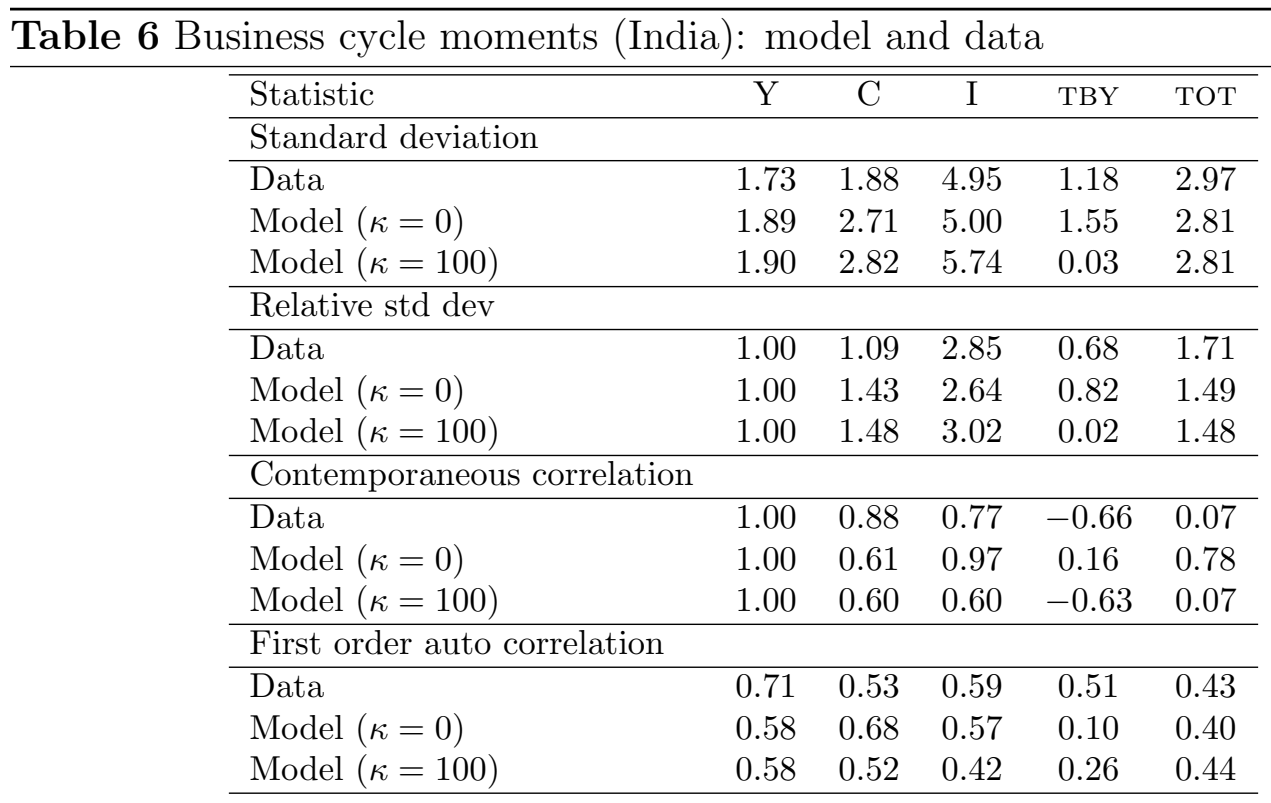

The table compares the moments from the data and the model, for the cases of full financial integration and no financial integration. For India, the model with no financial integration produces moments that match the data. Relative consumption volatility is higher than one and TBY is countercyclical. For $\kappa$ between 0 and 100, the relative volatility of TBY may match the data.

The model with productivity and terms of trade shocks, and low financial integration $(\kappa=100)$ does well in matching the features of the data. It is able to reproduce the higher relative consumption volatility, relative investment volatility and relative TOT volatility, as well as the highly countercyclical trade balance to output. The correlation of TOT with output also shows a good match.

For comparison, when $\kappa$ is small (the case of full financial integration), the relative volatility of trade balance to output ratio is high at 0.82 . However, when $\kappa$ is large (the case of financial autarky), the relative volatility is negligible. Again, in the case of small $\kappa$, the TBY is small at 0.16 , whereas when $\kappa$ is large, it is highly countercyclical at -0.63 . Depending on the extent of financial integration in India, for a $\kappa$ between 0 and 100, we can obtain moments for TBY that are close to the data. While the model with high $\kappa$ produces a high correlation of TOT with output at 0.78 , the model with low $\kappa$ produces a better match at 0.07 .

When there is a terms of trade shock, with full financial integration, agents can borrow or lend to continue consuming at the same level. Hence trade balance does not depend on the shock and is not correlated with output movements. When agents cannot borrow or lend, then following a positive terms of trade shock, their purchasing power increases, and they import more leading to a countercyclical trade balance to output ratio. Since trade has to balance each period, the volatility of TBY is low. 


\section{An economy with high financial openness}

We compare the results of the model to another type of emerging economy that is exposed to similar TOT shocks as India, but has higher relative financial openness. Using annual data (1995 - 2010), we calculate the moments for output, consumption, investment and тот for Brazil. ${ }^{5}$ The standard deviation of тот is 4.39 (for India the standard deviation is 6.39 using this data). As seen in Table 1, the ratio of trade openness to financial openness for Brazil is 0.29.

We assume the same deep parameters hold for Brazil and compare the moments from the model when $\kappa=0$ (the case of financial integration), and the data.

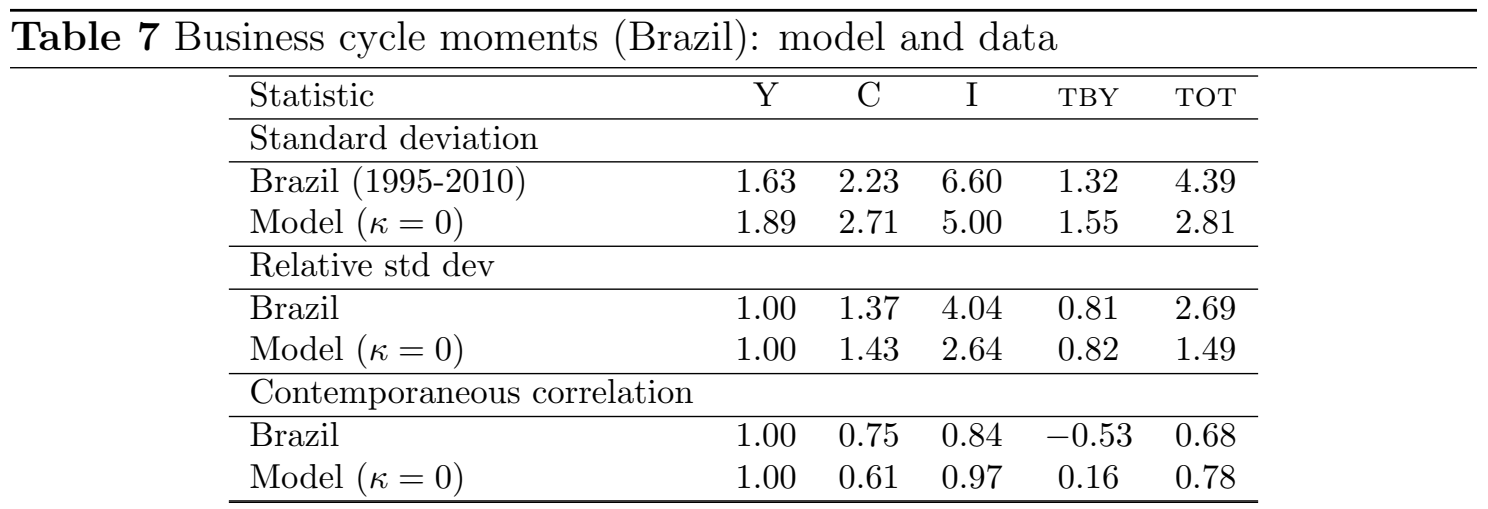

The table compares the moments from the data and the model, for the case of full financial integration in Brazil. The model reproduces the higher relative volatility of TBY.

As seen in Table 7, the model is able to match the relative volatility of trade balance to output ratio of 0.8 . With higher financial openness, the economy is not restricted to balance its current account, and hence its volatility is higher. The correlation of TOT with output is also high as in the data. However, the data for Brazil shows countercyclical trade balance to output at -0.53 , whereas the model produces a positive correlation when $\kappa=0$. As $\kappa$ increases to 100 , seen in the previous table, this correlation becomes negative. For an exact parametrisation of $\kappa$ between 0 and 100, for the Brazilian economy, we may be able to match this moment.

\section{Conclusion}

We show that emerging economies vary with regard to the level of openness of their current and capital accounts. Our results suggest that the nature of openness may influence their ability to absorb external shocks. We find that in the presence of terms of trade shocks, as financial openness increases, business cycle volatility decreases.

\footnotetext{
${ }^{5}$ Data on GDP, private consumption, gross fixed capital formation, exports and imports are obtained from IFS and data on net barter TOT are from WDI.
} 
We present a small open economy model with productivity and terms of trade shocks and calibrate it to Indian data. The model does well in matching the features of the data by replicating the higher relative consumption volatility, the countercyclical trade balance and the lower relative volatility of trade balance to output.

Empirical evidence on the relation between financial integration and macroeconomic volatility is ambiguous for emerging economies (Kose et al., 2003). Our model predicts that financial integration reduces business cycle volatility. But this is not true in general for an emerging economy. The degree of financial openness versus trade openness, and the relation to external shocks matter. Both these ideas have been explored to some extent in the empirical literature. One, the heterogeneity among emerging economies due to many reasons, including structural features (Kose et al., 2011); and two, the role of shocks in determining this relation (Razin and Rose, 1994). Similar to the implications of our result, von Hagen and Zhang (2006) suggest that pooling emerging economies with different levels of financial integration may not predict a significant relation between financial openness and volatility.

Our result has interesting policy implications. Emerging economies are subject to external shocks that may influence their business cycle. By increasing capital account openness, they can borrow and lend in international financial markets, which may help absorb shocks to the economy and stabilise the business cycle. Financial integration is, however, not without difficulties. This model, does not, for example, account for sudden stops or capital surges such as in Korinek (2011). Further, if capital flows to emerging economies are pro-cyclical as described in Kaminsky et al. (2005), the net effect may be to increase, rather than reduce the volatility of macroeconomic variables. Financial openness may expose the economy to financial shocks that may influence the business cycle as in Garcia-Cicco et al. (2010). These aspects should be considered in further research.

In this paper, we have abstracted from the effect of the exchange rate regime on the relation between external shocks and business cycle volatility. Flexibility in the exchange rate regime may be another channel that could help absorb external shocks as shown by (Broda, 2004). The role of exchange rate flexibility as well as its interaction with financial openness in stabilising the business cycle of an emerging economy that is exposed to TOT shocks is another area for further research. 


\section{References}

Abiad, A., T. Tressel, and E. Detragiache (2008). A new database of financial reforms, Volume 8. International Monetary Fund.

Aguiar, M. and G. Gopinath (2007). Emerging market business cycles: The cycle is the trend. Journal of Political Economy 115(1), 69-102.

Broda, C. (2004). Terms of trade and exchange rate regimes in developing countries. Journal of International Economics 63(1), 31-58.

Buch, C., J. Döpke, and C. Pierdzioch (2005). Financial openness and business cycle volatility. Journal of International Money and Finance 24(5), 744-765.

Cakici, S. (2011). Financial integration and business cycles in a small open economy. Journal of International Money and Finance 30(7), 1280-1302.

Chang, R. and A. Fernández (2010). On the sources of aggregate fluctuations in emerging economies. Working Paper No. 15938, National Bureau of Economic Research.

Chinn, M. and H. Ito (2008, September). A new measure of financial openness. Journal of Comparative Policy Analysis 10(3), 309-322.

Edwards, S. (1984). LDC foreign borrowing and default risk: An empirical investigation. American Economic Review 74 (4), 726-734.

Eichengreen, B. and A. Mody (2000). What explains changing spreads on emergingmarket debt. In S. Edwards (Ed.), Capital Flows and the Emerging Economies: Theory, Evidence, and Controversies, pp. 107-136.

Evans, M. and V. Hnatkovska (2007). International financial integration and the real economy. IMF Staff Papers 54(2), 220-269.

Garcia-Cicco, J., R. Pancrazi, and M. Uribe (2010). Real business cycles in emerging countries? American Economic Review 100(5), 2510-31.

Ghate, C., R. Pandey, and I. Patnaik (2013). Has India emerged? Business cycle stylized facts from a transitioning economy. Forthcoming, Structural Change and Economic Dynamics.

GOI (2011). Status Report on India's External Debt. External Debt Management Unit, Department of Economic Affairs, Ministry of Finance.

Kaminsky, G., C. Reinhart, and C. Végh (2005). When it rains, it pours: procyclical capital flows and macroeconomic policies. In NBER Macroeconomics Annual 2004, Volume 19, pp. 11-82. MIT Press.

Korinek, A. (2011). The New Economics of Capital Controls Imposed for Prudential Reasons. IMF Economic Review (59), 523-561.

Kose, A. (2002). Explaining business cycles in small open economies: How much do world prices matter? Journal of International Economics 56(2), 299-328.

Kose, A., E. Prasad, and A. Taylor (2011). Thresholds in the process of international financial integration. Journal of International Money and Finance 30(1), 147-179. 
Kose, A., E. Prasad, and M. Terrones (2003). Financial integration and macroeconomic volatility. IMF Working Paper.

Lane, P. and G. Milesi-Feretti (2007, November). The external wealth of nations mark II: Revised and extended estimates of foreign assets and liabilities, 1970-2004. Journal of International Economics 73, 223-250.

Levchenko, A. (2004). Financial liberalization and consumption volatility in developing countries. IMF.

Lubik, T. and W. Teo (2005). Do world shocks drive domestic business cycles? some evidence from structural estimation. Unpublished manuscript, Johns Hopkins University.

Mendoza, E. (1991). Real business cycles in a small open economy. The American Economic Review 81(4), 797-818.

Mendoza, E. (1995). The terms of trade, the real exchange rate, and economic fluctuations. International Economic Review 36(1), 101-137.

Min, H. (1998). Determinants of emerging market bond spread: Do economic fundamentals matter? Policy, Research Working Paper No. 1899, World Bank Publications.

Min, H., D. Lee, C. Nam, M. Park, and S. Nam (2003). Determinants of emerging-market bond spreads: Cross-country evidence. Global Finance Journal 14(3), 271-286.

Neumeyer, P. and F. Perri (2005). Business cycles in emerging economies: The role of interest rates. Journal of Monetary Economics 52(2), 345-380.

Patnaik, I. and A. Shah (2011). Did the indian capital controls work as a tool of macroeconomic policy? Working paper 2011-87, National Institute of Public Finance and Policy.

Patnaik, I., A. Shah, and G. Veronese (2011). How should inflation be measured in india. Economic and Political Weekly XLVI(16).

Quinn, D. and A. Toyoda (2007). Ideology and voter preferences as determinants of financial globalization. American Journal of Political Science 51(2), 344-363.

Razin, A. and A. Rose (1994). Business cycle volatility and openness: An exploratory cross-section analysis. In L. Leiderman and A. Razin (Eds.), Capital Mobility: The Impact on consumption, Investment and Growth, pp. 48 - 75. Cambridge University Press.

Schindler, M. (2009). Measuring financial integration: A new data set. IMF Staff Papers $56(1), 222-238$.

Uribe, M. and V. Yue (2006). Country spreads and emerging markets: Who drives whom? Journal of International Economics 69(1), 6-36.

Verma, R. (2008). The Service Sector Revolution in India. Research Paper No. 2008/72, United Nations University.

Virmani, A. (2004). Sources of India's Economic Growth: Trends in Total Factor Productivity. ICRIER Working Paper No. 131, Indian Council for Research on International Economic Relations. 
von Hagen, J. and H. Zhang (2006). Financial openness and macroeconomic volatility. Technical report, ZEI working paper. 